\title{
Testing the Efficiency of Leek (Allium ampeloprasum var. porrum) As A Preservative For The Iraqi Soft Cheese
}

\author{
Lamees T. Al- Hadedy, Jenen R. Hashem, Sawsan M.Abdul-rahman, \\ Wurood F. Ahmed \\ Food science dept., college of agriculture/University of Baghdad, Iraq
}

\begin{abstract}
In order to estimate the antimicrobial activity of leek, blender smashed washed fresh leek was added under aseptic conditions to four partitions of a freshly prepared curd of the Iraqi soft cheese each of $250 \mathrm{~g}$ weight before the compressing process. The addition ratio were performed at four levels $5,10,20,30 \mathrm{~g}$ smashed leek/ $\mathrm{kg}$ cheese curd. After that all treatments in addition to the control sample was compressed by using cheese molds and packed in a clean sterile containers. Samples were stored at $7^{\circ} \mathrm{C}$ for 12 days, and every three days of the storage the microbiological and sensory tests were performed. Total count, Coliforms, psychrophilic bacteria, yeast and molds counts were evaluated. Results of the control ( untreated) sample of the Iraqi soft cheese showed gradient increase in all of referred to organisms along storage period. While the antimicrobial activity of leek clearly depends on its addition ratio as $30 \mathrm{~g} / \mathrm{kg}$ was the best for decreasing the total count, Coliforms, psychrophilic bacteria, yeast and molds counts . Results of sensory evaluation after 0,3, 6 and 9 days of storage obtained insignificant differences between the control and the other treatments samples in color, and bitterness except significant increasing in the day 9 at the addition ratio $30 \mathrm{~g} / \mathrm{kg}$. Significant increasing was detected in the flavor and general acceptance for the treatments in levels 10,20 and $30 \mathrm{~g} / \mathrm{kg}$ in the comparison with control for the above storage periods. While these differences were all significant after 12 days of storage for all samples for all of the sensory characters studied specially for the flavor and bitterness in comparison with the control. Therefore, leek may be successfully used as a preservative and pleasant flavor enhancer for the Iraqi soft cheese.
\end{abstract}

Keywords: leek soft cheese Coliforms, psychrophilic bacteria, yeast and molds

\section{Introduction}

It is no secret that the most important consideration by food manufacturers is to prolong the duration of safe storage without damage or change in the sensory qualities and nutritional value with a focus on maintaining safety in terms of microbial, which requires a continuous fight for microorganisms causing food damage Or that make them unsafe by stopping or slowing down the damage that causes huge annual losses of billions of dollars [Kaur, 2007; Rasooli, 2007] Because traditional conservation methods cause damage to sensory and nutritional traits and as a result of increased consumer awareness, the trend towards the use of natural alternatives for conservation methods such as medicinal plants and herbs [Ghosh et al., 2011, Stonsaovapak S. et al., 2000] Hits anti Maekerobac oils and plant extracts is the basis for many applications, including raw food manufacturer save [Hammer et al., 1999].

Some plant tissue containing, including shallots, some with damper influence growth microbiologists substances as part of the defense mechanisms have against certain pathological neighborhoods, which had thus found its way into food industries as preservatives for food against spoilage microbial [Tana, et al., 2015; Agatemor, 2009]. Shallots Allium ampeloprasum var. porrum of widespread plants worldwide and commonly used in spicing food, particularly authorities in many European countries like Britain, Belgium, the Mediterranean, Iraq [Daniel and Maria, 2000]. It is a taste and smell close onions Each cup (89 grams) of fresh shallots 54 calories and 0.27 fats all unsaturated and $12.59 \mathrm{~g}$ carbohydrates, 1.6 fibers and 1.33 protein, 0 grams cholesterol, according to the US Department of Agriculture also has Iron, sulfur, magnesium, calcium, zinc, phosphorus, potassium and vitamins $\mathrm{A}, \mathrm{B}, \mathrm{C}$ and $\mathrm{E}$ for the legume benefits in combating cancer and erectile dysfunction of men and women and diuretics, softening the abdomen, treating hemorrhoids, cleaning the intestines, stabilizing sugar and giving a sense of satiety to dieters to lose weight and cure colds, Throat and asthma Cough and expectorate and the expansion of the bronchial expelled free radicals causing cancer has a role in generating and stimulating red blood cells, building and repairing bones and fight kings, rheumatism, diabetes. But not recommended for those suffering from colon problems and flatulence [https://en.wikipedia.org/wiki/Leek]. Antimicrobial efficacy of many plants has been identified [Vriens K. et al., 2014; Cabral L.D.C. Et al., 2013], especially allium species, including leeks, have long been associated with bacteria, fungi, viruses and parasites, especially those resistant to antimicrobial agents such as staphylococcus aureus for its rich amino acid which contains group SH-. [Kyu,2012;Nile and Park, 2014] and supports the content of the sulfur compounds to the soil of the development of the content of sulfur compounds [Packia et al., 
Testing The Efficiency of Leek (Allium ampeloprasum var. porrum) As A Preservative For The ..

2015]. The addition of leeks to food does not require special legislation because it is originally a food component and is known to be generally safe [FDA, 2009]. I have been using leeks in addition to other types of plants to sex garlic Allium such as anti-success Maekerobac [Sergio, et al., 2013].

Therefore, the goal of this research to assess the efficiency shallots in prolong keeping soft cheese Iraqi and determine the optimal addition of hand damper influence the proportion taking into account its impact on the sensory qualities to tackle the problem of the short duration of conservation of cheeses soft Iraqi outstanding high proportion of humidity (60-65\%) And does not contain any kind of primer. [Painting, 1983].

\section{Cheese models and transactions:}

\section{Materials and Methods}

It was obtained thrombus soft cheese Iraqi models of one of the Abu Ghraib area in the province of Baghdad in Iraq plants in pre outsole thrombus in cheese molds. The thrombus was divided into five equal parts, each weighing $250 \mathrm{~g}$ and three replicates per treatment. Transactions included under sterile conditions in addition pureed fresh shallots Balkhalat well after wash water sterilized distilled, so by 5, 10, 20, $30 \mathrm{~g}$ leek mashed / $\mathrm{kg}$ thrombus emphasizing the homogeneous distribution of pureed leeks to all parts of the thrombus. The fifth treatment included the addition of leeks as a control control treatment. The thrombus was cut into sterile cheese molds and in sterile conditions, and the resulting cheese was packed in clean and sterile containers. The samples were stored at $7^{\circ} \mathrm{C}$ for 12 days during which macroscopic and sensory tests were conducted every three consecutive days of storage.

\section{Microbiological tests:}

In the days $(0,3,6.9,12)$, the tests were conducted according to Harrigan and McCance [Harrigan WF and McCance, ME, 1976.] $1 \mathrm{~mL}$ of the appropriate dilution was applied to the dishes and Nutrient Agar was used to estimate the total number of bacteria and to estimate the number of cold bacteria and Potato Dextrose Agar for the determination of yeasts and molds, McConcky Agar for colorectal colonization) was incubated at $37^{\circ} \mathrm{C}$ for 24 hours to estimate the total number of bacteria Of the coliform, while the incubation temperature of $7^{\circ} \mathrm{C}$ for 7 days to estimate the number of psychrotrophic. As the lap of dishes grade molds and yeasts temperature of $25^{\circ} \mathrm{C}$ for 5 days.

\section{Sensory assessment:}

Samples of different cheese treatments were evaluated at storage intervals $(0,3,6,9,12)$ days, based on seven experienced residents of the teaching and research staff in the Food Science Department / College of Agriculture / University of Baghdad. The sensory evaluation form included color, flavor, bitterness and general acceptance, each of which was given 5 grades according to the form of sensory evaluation proposed by [AlDahan, 1977].

\section{Results}

(Table 1) shows a gradual increase in the total number of bacteria by increasing the storage period for Iraqi soft-shelled chicken (control treatment), which increased from $8 \times 10^{4}$ after processing Directly to $20 \times 10$ ${ }^{6}$ cells / g after 12 days of storage at $7^{\circ} \mathrm{C}$. Although the total number of bacteria decreased in all leachate treatments compared with control, the treatment added to the leeks at $30 \mathrm{~g} / \mathrm{kg}$ resulted in elimination On most bacteria after 9 days of storage. The treatment with the addition of leeks at $20 \mathrm{~g} / \mathrm{kg}$ was required for 12 days to reach the same effect. This is true for the number of cold-friendly bacteria.( Table 2) shows that the number of bacteria in control treatment increased with the duration of the storage period, while the number of cold-friendly bacteria decreased in all the leeks to cheese. Addition of $30 \mathrm{~g} / \mathrm{kg}$ was added to 6 days to eliminate all Coldtreated bacteria. The treatment required $20 \mathrm{~g} / \mathrm{kg}$ to 12 days to obtain the same effect. When examining the effect of leeks in the colon bacteria, it is noted in (Table 3) that the increase in the number of storage time progress in the treatment of control, while none of the treatment after $20,30 \mathrm{~g} / \mathrm{kg}$ after 3 days of storage only, or after six days of treatment with 5 Or $10 \mathrm{~g}$ of leeks / $\mathrm{kg}$ thrombus. When examining the effect of leeks in yeasts and molds, as shown in (Table 4), it was found that their numbers were increasing in the control treatment for the duration of the storage period, while the numbers in all other treatments decreased to zero after 12 days of storage in the treatment with a concentration of $5 \mathrm{~g} / 9$ days for $10,20 \mathrm{~g} / \mathrm{kg}$, and 3 days for treatment with a concentration of $30 \mathrm{~g} / \mathrm{kg}$. The results are consistent with those of [ Samia, Atta 1997, Rodriguez et al. 1998, Janabi 2008, Al-Ani , 2006 and Ahmeed and Hashim 2009], when studying the effect of different plant extracts such as raw garlic, watercress and black bean potato husks in microbiology. In this regard, it is possible to say that leeks are included in the list of natural substances that can prolong the length of the Iraqi soft cheese casserole, which is characterized by low storage capacity compared to other types of cheese. . 
Testing The Efficiency of Leek (Allium ampeloprasum var. porrum) As A Preservative For The ..

Table 1: Effect of adding different proportions of leeks in the number of Total Bacteria Counts in Iraqi soft cheese

\begin{tabular}{|c|c|c|c|c|c|c|}
\hline \multirow[t]{2}{*}{ Sequence } & \multirow{2}{*}{$\begin{array}{c}\text { Treatment } \\
\operatorname{curd}(\mathrm{kg}) / \text { Leek }(\mathrm{g})\end{array}$} & \multicolumn{5}{|c|}{ Length of storage(day ) } \\
\hline & & $\mathbf{0}$ & 3 & 6 & 9 & 12 \\
\hline 1 & $($ control )0 & ${ }^{4} 10 \times 8$ & ${ }^{4} 10 \times 3.6$ & ${ }^{4} 10 \times 70$ & ${ }^{5} 10 \times 30$ & ${ }^{6} 10 \times 20$ \\
\hline 2 & 5 & ${ }^{4} 10 \times 7.5$ & ${ }^{4} 10 \times 1.5$ & ${ }^{3} 10 \times 8.5$ & ${ }^{3} 10 \times 9.5$ & ${ }^{3} 10 \times 8$ \\
\hline 3 & 10 & ${ }^{4} 10 \times 7.6$ & ${ }^{3} 10 \times 6$ & ${ }^{2} 10 \times 4$ & ${ }^{2} 10 \times 2.6$ & ${ }^{2} 10 \times 1.1$ \\
\hline 4 & 20 & ${ }^{4} 10 \times 7.2$ & ${ }^{2} 10 \times 2$ & $10 \times 9$ & $10 \times 0.8$ & ---- \\
\hline 5 & 30 & ${ }^{4} 10 \times 7.7$ & $10 \times 2$ & $10 \times 0.7$ & ---- & ---- \\
\hline
\end{tabular}

Table 2: Effect of adding different proportions of leeks in the number of Psychrophiles in Iraqi soft cheese

\begin{tabular}{|c|c|c|c|c|c|c|}
\hline \multirow[t]{2}{*}{ Sequence } & \multirow{2}{*}{$\begin{array}{c}\text { Treatment } \\
\operatorname{curd}(\mathrm{kg}) / \text { Leek }(\mathrm{g})\end{array}$} & \multicolumn{5}{|c|}{ Length of storage(day ) } \\
\hline & & $\mathbf{0}$ & $\mathbf{3}$ & 6 & 9 & 12 \\
\hline 1 & (control) 0 & ${ }^{4} 10 \times 5$ & ${ }^{4} 10 \times 78$ & ${ }^{5} 10 \times 1.2$ & ${ }^{5} 10 \times 4.3$ & ${ }^{6} 10 \times 6$ \\
\hline 2 & 5 & ${ }^{3} 10 \times 4.5$ & ${ }^{3} 10 \times 1.8$ & ${ }^{3} 10 \times 6.1$ & ${ }^{3} 10 \times 7.2$ & ${ }^{3} 10 \times 5$ \\
\hline 4 & 20 & ${ }^{4} 10 \times 5.1$ & $10 \times 47$ & $10 \times 3.1$ & $10 \times 1.8$ & $10 \times 3.7$ \\
\hline 5 & 30 & ${ }^{4} 10 \times 5.6$ & $10 \times 9.6$ & ---- & --- & ---- \\
\hline
\end{tabular}

Table 3: Effect of adding different proportions of leeks in the number of yeasts and molds in Iraqi soft cheese

\begin{tabular}{|c|c|c|c|c|c|c|}
\hline \multirow{2}{*}{ Sequence } & $\begin{array}{c}\text { Treatment } \\
\text { curd(kg)/Leek (g) }\end{array}$ & \multicolumn{5}{|c|}{ Length of storage(day ) } \\
\cline { 3 - 7 } & & $\mathbf{0}$ & $\mathbf{3}$ & $\mathbf{6}$ & $\mathbf{9}$ & $\mathbf{1 2}$ \\
\hline $\mathbf{1}$ & & $10 \times 5$ & $10 \times 7.1$ & $10 \times 9.2$ & ${ }^{2} 10 \times 6$ & ${ }^{2} 10 \times 8.7$ \\
\hline $\mathbf{2}$ & $\mathbf{5}$ & ${ }^{4} 10 \times 7.5$ & $10 \times 1$ & ---- & ---- & --- \\
\hline $\mathbf{3}$ & $\mathbf{1 0}$ & ${ }^{4} 10 \times 7.6$ & $10 \times 0.7$ & --- & ---- & -- \\
\hline $\mathbf{4}$ & $\mathbf{2 0}$ & ${ }^{4} 10 \times 7.2$ & ---- & --- & -- & - \\
\hline $\mathbf{5}$ & $\mathbf{3 0}$ & ${ }^{4} 10 \times 7.7$ & ---- & --- & -- & - \\
\hline
\end{tabular}

Table 4: Effect of adding different proportions of leeks in the number of total Coliform in Iraqi soft cheese

\begin{tabular}{|c|c|c|c|c|c|c|}
\hline \multirow[t]{2}{*}{ Sequence } & \multirow{2}{*}{$\begin{array}{l}\text { Treatment } \\
\operatorname{curd}(\mathrm{kg}) / \text { Leek (g) }\end{array}$} & \multicolumn{5}{|c|}{ Length of storage(day ) } \\
\hline & & $\mathbf{0}$ & 3 & 6 & 9 & 12 \\
\hline 1 & (control) 0 & ${ }^{2} 10 \times 9.7$ & ${ }^{2} 10 \times 8.4$ & ${ }^{3} 10 \times 7.6$ & ${ }^{4} 10 \times 2.7$ & ${ }^{4} 10 \times 8.8$ \\
\hline 2 & 5 & ${ }^{2} 10 \times 5.7$ & ${ }^{2} 10 \times 1.6$ & $10 \times 6.2$ & $10 \times 9.5$ & ---- \\
\hline 3 & 10 & ${ }^{2} 10 \times 4.5$ & $10 \times 9.3$ & $10 \times 4.2$ & ---- & ---- \\
\hline 4 & 20 & ${ }^{2} 10 \times 4.1$ & $10 \times 6$ & $10 \times 1.2$ & ---- & --- \\
\hline 5 & 30 & ${ }^{2} 10 \times 2.1$ & ---- & ---- & -ב-- & ב--- \\
\hline
\end{tabular}

(Table 5) shows the results of the statistical analysis of the sensory characteristics of the Iraqi soft cheese models, with different rates of leeks and different storage periods, varying from 0 to 12 days, and three days from one evaluation date to another.

Table 5: Sensory Evaluation Of Iraqi soft cheese add to it leeks at different rates (5 grades for each of the traits studied)

\begin{tabular}{|c|c|c|c|c|c|}
\hline $\begin{array}{c}\text { Treatment } \\
\operatorname{curd}(\mathrm{kg}) / \text { Leek }(\mathrm{g})\end{array}$ & $\begin{array}{c}\text { Length of } \\
\text { storage(day ) }\end{array}$ & color & bitterness & Flavor & $\begin{array}{c}\text { General } \\
\text { Acceptance }\end{array}$ \\
\hline \multirow{5}{*}{ (control) 0} & $\mathbf{0}$ & $5 \mathrm{~A}$ & $4.8 \mathrm{~A}$ & $4.5 \mathrm{~A}$ & $4.5 \mathrm{~A}$ \\
\hline & 3 & $4.5 \mathrm{~A}$ & $4.6 \mathrm{~A}$ & $4.2 \mathrm{~A}$ & $4.2 \mathrm{~A}$ \\
\hline & 6 & $4.1 \mathrm{~A}$ & $4 \mathrm{~A}$ & $4 \mathrm{~A}$ & $3.9 \mathrm{~A}$ \\
\hline & 9 & $3.2 \mathrm{~A}$ & $2.5 \mathrm{~A}$ & $2.8 \mathrm{~A}$ & $3.1 \mathrm{~A}$ \\
\hline & 12 & $1.2 \mathrm{~A}$ & $1.2 \mathrm{~A}$ & $1.1 \mathrm{~A}$ & $2 \mathrm{~A}$ \\
\hline \multirow{5}{*}{5} & $\mathbf{0}$ & $4.8 \mathrm{~A}$ & $5 \mathrm{~A}$ & $4.6 \mathrm{~A}$ & $4.6 \mathrm{~A}$ \\
\hline & 3 & $4.5 \mathrm{~A}$ & $4.8 \mathrm{~A}$ & $4.3 \mathrm{~A}$ & $4.7 \mathrm{~A}$ \\
\hline & 6 & $3.5 \mathrm{~A}$ & $4.3 \mathrm{~A}$ & $3.9 \mathrm{~A}$ & $4 \mathrm{~A}$ \\
\hline & 9 & $3 \mathrm{~A}$ & $3.8 \mathrm{~A}$ & $3 \mathrm{~A}$ & $3.2 \mathrm{~A}$ \\
\hline & 12 & $2.5 \mathrm{~B}$ & $2.3 \mathrm{~B}$ & $2 \mathrm{~B}$ & $2.4 \mathrm{~B}$ \\
\hline \multirow{5}{*}{10} & $\mathbf{0}$ & $4.9 \mathrm{~A}$ & $4.9 \mathrm{~A}$ & $5 \mathrm{~B}$ & $5 \mathrm{~B}$ \\
\hline & 3 & $4.3 \mathrm{~A}$ & $4.8 \mathrm{~A}$ & $4.8 \mathrm{~B}$ & $4.9 \mathrm{~B}$ \\
\hline & 6 & $3.8 \mathrm{~A}$ & $4.2 \mathrm{~A}$ & $4.2 \mathrm{~B}$ & $4.5 \mathrm{~B}$ \\
\hline & 9 & $3.3 \mathrm{~A}$ & $2.9 \mathrm{~A}$ & $3.5 \mathrm{~B}$ & $4 \mathrm{~B}$ \\
\hline & 12 & $2.9 \mathrm{~B}$ & $2.5 \mathrm{~B}$ & $2.3 \mathrm{~B}$ & $2.7 \mathrm{~B}$ \\
\hline \multirow{5}{*}{20} & $\mathbf{0}$ & $4.8 \mathrm{~A}$ & $4.9 \mathrm{~A}$ & $5 \mathrm{~B}$ & $5 \mathrm{~B}$ \\
\hline & 3 & $4.7 \mathrm{~A}$ & $4.9 \mathrm{~A}$ & $4.8 \mathrm{~B}$ & $4.9 \mathrm{~B}$ \\
\hline & 6 & $3.5 \mathrm{~A}$ & $4.2 \mathrm{~A}$ & $4.5 \mathrm{~B}$ & $4.5 \mathrm{~B}$ \\
\hline & 9 & $3.1 \mathrm{~A}$ & $2.8 \mathrm{~A}$ & $3.3 \mathrm{~B}$ & $4.2 \mathrm{~B}$ \\
\hline & 12 & $3 \mathrm{~B}$ & $2.5 \mathrm{~B}$ & $2.5 \mathrm{~B}$ & $2.8 \mathrm{~B}$ \\
\hline
\end{tabular}


Testing The Efficiency of Leek (Allium ampeloprasum var. porrum) As A Preservative For The ..

\begin{tabular}{|c|c|c|c|c|c|}
\hline \multirow{4}{*}{30} & $\mathbf{0}$ & $4.7 \mathrm{~A}$ & $4.9 \mathrm{~A}$ & $5 \mathrm{~B}$ & $5 \mathrm{~B}$ \\
\cline { 2 - 6 } & $\mathbf{3}$ & $4.7 \mathrm{~A}$ & $4.9 \mathrm{~A}$ & $4.9 \mathrm{~B}$ & $4.9 \mathrm{~B}$ \\
\cline { 2 - 7 } & $\mathbf{6}$ & $3.7 \mathrm{~A}$ & $4.5 \mathrm{~A}$ & $4.7 \mathrm{~B}$ & $4.7 \mathrm{~B}$ \\
\cline { 2 - 7 } & $\mathbf{9}$ & $3.5 \mathrm{~B}$ & $3.5 \mathrm{~B}$ & $3.5 \mathrm{~B}$ & $2.3 \mathrm{~B}$ \\
\cline { 2 - 6 } & $\mathbf{1 2}$ & $3 \mathrm{~B}$ & $3.2 \mathrm{~B}$ & $2.8 \mathrm{~B}$ & $2.8 \mathrm{~B}$ \\
\hline
\end{tabular}

There were no significant differences between control and other treatments for color and bitterness in days $0,3,6$, and 9 of storage except for significant increase of these two levels on the ninth day of the concentration of $30 \mathrm{~g} / \mathrm{kg}$. The table also showed a significant increase in flavor and general acceptance levels for the addition levels of 10,20 and $30 \mathrm{~g} / \mathrm{kg}$ in all storage days. The results showed a significant increase in all levels of addition in all traits and in all storage days. The steady decline in sensory traits may be due to the increased concentration of leeks to its inhibitory action in the macrophages causing cheese damage, as opposed to the control treatment free of any inhibitors, accompanied by a clear and rapid deterioration of these traits. It is also noted that this deterioration can be reduced and not prevented by the slow extraction of the components of leeks into the cheese block and then work to inhibit the microorganisms and on the other hand, the action of enzymes of those neighborhoods will remain valid within this cheese and thus slow damage to it by increasing storage time. Hence the importance of the added concentration of leeks on both its ability to preserve cheese on the one hand and the new sensory qualities it adds to cheese, which has been highly acclaimed by the residents. Based on this, it is possible to infer the possibility of using leeks as a preservative for Iraqi soft cheese because of its conservatism and its sensual characteristics.

\section{Conclusion}

This study showed, the success of using leeks as a preservative to length of storage of soft Iraqi cheese, where the addition was at the level of $30(\mathrm{~g})$ leek / $(\mathrm{kg})$ curd Best Compared with other transactions. Where led to Dispose of bacteria during 9 days, while increasing the number of bacteria in control. . In addition to the leeks added a new flavor of Iraqi soft cheese and led to the improvement and increase consumer acceptance

\section{References}

[1]. Kaur, K. 2007. Evaluation of the potential use of Ginger as a fruit preservative. Biology Department, Skyline college,San Bruno CA. http://www.smcc.net/account/case/sacnas/2007/kim.pdf

[2]. Rasooli, I. 2007. Food preservation: A biopreservative approach. Food, 1(2): 111-136

[3]. Ghosh, A.K., Banerjee S., H. I. Mullick and Banerjee J. 2011. Zingiber officinale: A natural gold. Int. J. of pharma and Bio. Sci. 2(1): 283-294.

[4]. Stonsaovapak S., chareonthamawat p. and Boonyaratanakornkit M. 2000. Inhibitary effects of selected Thai spices and medicinal plants on Escherichia coli O157:H7 and Yersinia enterocolitica. Kasetsart J. (Nat. Sci.) 34:510-517.

[5]. K. A. Hammer, C. F. Carson, T. V. Riley. June 1999. Antimicrobial activity of essential oils and other plant extracts. J. of applied microbiology, 86(6):985-990.

[6]. Tana Hintz, Karl K. Matthews and Rong Di. 2015. The use of plant antimicrobial compounds for food preservation. BioMed Research International. Volume 2015 (2015), Article ID 246264, 12 pages..

[7]. Agatemore, C. 2009. Antimicrobial activity of aqueous and ethanol extracts of nine Nigerian spices against four food borne bacteria. EJEAF Che., 8(3): 95-200.

[8]. Daniel Zohary and Maria Hopf, Domestication of plants in the Old World, third edition (Oxford: Oxford University Press, 2000), p. 195.

[9]. https://en.wikipedia.org/wiki/Leek

[10]. K. Vriens, B. P. A. Cammue, and K. Thevissen, "Antifungal plant defensins: mechanisms of action and production," Molecules, vol. 19 , no. 8, pp. 12280-12303, 2014

[11]. L. D. C. Cabral, V. F. Pinto, and A. Patriarca, 2013. Application of plant derived compounds to control fungal spoilage and mycotoxin production in foods," International Journal of Food Microbiology, vol. 166, no. 1, pp. 1-14.

[12]. Kyu Hang Kyung, April 2012. Antimicrobial properties of allium species. Current Opinion in Biotechnology. 23(2):142-147.

[13]. S. H. Nile and S. W. Park, 2014. Edible berries: bioactive components and their effect on human health," Nutrition, vol. 30, no. 2, pp. 134-144.

[14]. Packia Lekshmi NCJ, Viveka S., Jeeva S. and Raja Brindha J. 2015. Antimicrobial spectrum of Allium species- A review. Indian Journal of science.15(44): 1-5.

[15]. U.S. Food and Drug Administration, July 1999. Guidance for industry: food antimicrobial additives.

[16]. Sergio Casella, Michele Leonardi, Bernardo Melai, Filippo Fratini and Luisa Pistelli. March 2013. Phytotherapy Research, 27(3):317- 474.

[17]. Harrigan WF. And McCance, M.E., 1976. Laboratory Methods in Food and Dairy Microbiology. Academic Press, London,UK, P. 125-156.

[18]. Al-Dahan, Aamer Hamid Saeed. 1983. Effect of cheese industry and its types in the world. Dar Al Hekma Press. Mosul. Iraq. P. 88.

[19]. Samia , E. and Atta, A.H. 1997. Antimicrobial and antioxidant effect of crude garlic extraction meat. Vet. Med. J., Giza. 45(1): $37-$ 45 
Testing The Efficiency of Leek (Allium ampeloprasum var. porrum) As A Preservative For The ..

[20]. Rodriguez, D.S., M. Hadly and C. Walf- Hall. 1998. Potato peel extract a non mutagenic antimicrobial activity. J. of Food Sci., 63(5): 907-910.

[21]. Janabi, Nidal Mohammed .2008. Effect of some plant extracts as antimicrobial agents and antioxidants in some diets. PhD, Department of Food Science and Biotechnology, Faculty of Agriculture, University of Baghdad. R: 38-78.

[22]. Al-Ani, A.H.J. 2006. Effect of some plant extracts on food spoilage microorganisms and their application to extend the shelf life of the soft cheese. Ph.D. Thesis. Dept. of Biology, College of Sci. University of Mustansiriya. P. 138.

[23]. Ahmeed, Asma Sabah and Hashem, Janan Razak .2009. Effect of adding watercress to Iraqi soft cheese as a preservative. Journal of Agricultural Sciences of Iraq, 40 (2): 120-125. 